\title{
Effects of Opiate Drugs on Fas-Associated Protein with Death Domain (FADD) and Effector Caspases in the Rat Brain: Regulation by the ERKI/2 MAP Kinase Pathway
}

\author{
María-Julia García-Fuster', Antonio Miralles' and Jesús A García-Sevilla*,' \\ 'Laboratori de Neurofarmacologia, Institut Universitari d'Investigació en Ciències de la Salut (IUNICS), Universitat de les Illes Balears, Palma de \\ Mallorca, Balears, Spain
}

\begin{abstract}
This study was designed to assess the effects of opiate treatment on the expression of Fas-associated protein with death domain (FADD) in the rat brain. FADD is involved in the transmission of Fas-death signals that have been suggested to contribute to the development of opiate tolerance and addiction. Acute treatments with high doses of sufentanil and morphine ( $\mu$-agonists), SNC-80 ( $\delta$-agonist), and U50488H ( $\kappa$-agonist) induced significant decreases (30-60\%) in FADD immunodensity in the cerebral cortex, through specific opioid receptor mechanisms (effects antagonized by naloxone, naltrindole, or nor-binaltorphimine). The cannabinoid CB, receptor agonist WIN 55,212-2 did not alter FADD content in the brain. Chronic (5 days) morphine (10-100 mg/kg), SNC-80 (I0 mg/kg), or U50488H $(10 \mathrm{mg} / \mathrm{kg})$ was associated with the induction of tachyphylaxis to the acute effects. In morphine- and SNC-80-tolerant rats, antagonistprecipitated $(2 \mathrm{~h})$ or spontaneous withdrawal $(24-48 \mathrm{~h}$ ) induced a new and sustained inhibition of FADD (I3-50\%). None of these treatments altered the densities of caspases $8 / 3$ (including the active cleaved forms) in the brain. Pretreatment of rats with SL 327 (a selective MEKI/2 inhibitor that blocks ERK activation) fully prevented the reduction of FADD content induced by SNC-80 in the cerebral cortex (43\%) and corpus striatum (29\%), demonstrating the direct involvement of ERKI/2 signaling in the regulation of FADD by the opiate agonist. The results indicate that $\mu$ - and $\delta$-opioid receptors have a prominent role in the modulation of FADD (opposite to that of Fas) shortly after initiating treatment. Opiate drugs (and specifically the $\delta$-agonists) could promote survival signals in the brain through inhibition of FADD, which in turn is dependent on the activation of the antiapoptotic ERKI/2 signaling pathway.

Neuropsychopharmacology (2007) 32, 399-4II. doi:I0. I038/sj.npp. I301040; published online 8 February 2006
\end{abstract}

Keywords: FADD; caspases 8/3; opiate agonists and antagonists; opiate addiction; WIN 55,2 I2-2; ERKI/2; MEK inhibition (SL 327); rat brain

\section{INTRODUCTION}

Fas (APO-1) is a cell surface receptor glycoprotein belonging to the tumor necrosis/nerve growth factor superfamily (Nagata and Golstein, 1995), which plays a major role in apoptosis (MacEwan, 2002). Following trimerization of Fas after ligation with Fas-L, the receptor rapidly recruits procaspase- 8 through the key adaptor protein called Fas-associated protein with death domain (FADD) (Chinnaiyan et al, 1995) that transmitts the death signal (Algeciras-Schimnich et al, 2002; Henkler et al, 2005). FADD protein carries a death domain (DD) at its C-terminal region, involved in the binding of Fas, which also displays a single serine phosphorylation site that is essential, inter

\footnotetext{
* Correspondence: Dr JA García-Sevilla, Laboratory of Neuropharmacology, IUNICS, University of the Balearic Islands, Cra. Valldemossa km 7.5, Palma de Mallorca, Balears E-07|22, Spain, Tel: + I 34971 |73|48, Fax: + | 34 97| |73|84, E-mail: jesus.garcia-sevilla@uib.es Received 17 June 2005; revised 22 November 2005; accepted 8 December 2005

Online publication: 5 January 2006 at http://www.acnp.org/citations/ Npp0 I0506050400/default.pdf
}

alia, for cell cycle regulation and survival/proliferation in some cells (Scaffidi et al, 2000; Zhang et al, 2004). The $\mathrm{N}$-terminal domain of FADD is called the death effector domain (DED) and is responsible for recruiting procaspase8 , which after dimerization is autoactivated to a mature enzyme with the initiation of apoptosis (Tourneur et al, 2005). FADD is expressed in the cytoplasm and nucleus (Gómez-Angelats and Cidlowski, 2003), but upon Fas ligation cytoplasmic FADD is rapidly recruited to the plasma membrane, where it forms, together with Fas and procaspase-8, the so-called death-inducing signaling complex (DISC) (Kischkel et al, 1995; Algeciras-Schimnich et al, 2002). In type I cells (not dependent on mitochondrial signal amplification) (Barnhart et al, 2003), caspase-8 directly activates downstream effector caspases (eg caspases-3/6/7), allowing cleavage of numerous substrates leading to cell death (Cohen, 1997; MacEwan, 2002). Fasinduced death in the nervous system (Felderhoff-Mueser et al, 2000) was shown to share the same basic mechanisms with peripheral cells (Sastry and Rao, 2000).

Besides the role of Fas/FADD in apoptosis, there are now solid evidences that also demonstrate the relevance of this 
system in the regulation of cell growth and differentiation (Budd, 2002; Tibbetts et al, 2003) and in regenerative responses in neurons (Desbarats et al, 2003; Lambert et al, 2003). These nonapoptotic roles for Fas/FADD are still poorly understood and may involve the activation of the ERK1/2 MAPK pathway, which is important for antiapoptotic signals (Holmström et al, 1999, 2000; Wada and Penninger, 2004) and for the regulation of synaptic plasticity, learning, and memory (Kyosseva, 2004).

During the last few years, various chronic effects of heroin/morphine on the structure of neurons have been interpreted to indicate that opiate drugs might induce neuronal damage after long-term exposure (see Nestler, 1996; Büttner et al, 2000; Ferrer-Alcón et al, 2000). In this context, Fas proteins (native and glycosylated receptor, and complexes of monomers relevant in Fas signaling) were shown to be upregulated after chronic heroin and morphine treatments and heroin withdrawal in rat brain (Boronat et al, 2001; García-Fuster et al, 2003a, 2004a), which suggested a role for Fas in opiate addiction either as promoter of abnormal cell death (see Yin et al, 1999; Wang et al, 2002) or as a possible nonapoptotic signal transducer of opioid receptors (see Tegeder and Geisslinger, 2004). To clarify this issue, the present study was designed to assess the modulation of FADD (the transmitter of Fas signal) and effector caspase- $8 / 3$ in the brain after the acute and chronic treatments with selective $\mu$-, $\delta$-, and $\kappa$-opioid peptide (MOP-, DOP-, and KOP-) receptor agonists, and during the induction of opiate withdrawal in rats. Since the activation of some MAPK pathways is relevant for antiapoptotic signals (see above), the possible involvement of ERK1/2 signaling in the effect of a $\delta$-agonist on FADD was also investigated. A preliminary account of this work was given at the XXV Congress of the Spanish Society of Pharmacology (García-Fuster et al, 2003b).

\section{MATERIALS AND METHODS}

\section{Drug Treatment of Rats}

Adult male Sprague-Dawley rats (200-250 g) were used. They were housed under controlled environmental conditions $\left(22^{\circ} \mathrm{C}, 70 \%\right.$ humidity, and 12 -h light/dark cycle) with free access to a standard diet and tap water. The rats were treated in accordance with the NIH Guidelines for the Care and Use of Laboratory Animals (1985) and in agreement with the local ethical committee. For the acute treatments with opiate agonists, the rats received a single intraperitoneal (i.p.) or subcutaneous (s.c.) injection of sufentanil $(1-30 \mu \mathrm{g} / \mathrm{kg}$, s.c., $30 \mathrm{~min}$, or $15 \mu \mathrm{g} / \mathrm{kg}$ for $30-120 \mathrm{~min})$, morphine $(3-100 \mathrm{mg} / \mathrm{kg}$, i.p., $2 \mathrm{~h}$ ), SNC-80 (a selective $\delta$-agonist, $1-10 \mathrm{mg} / \mathrm{kg}$, i.p., $30 \mathrm{~min}$, or $10 \mathrm{mg} / \mathrm{kg}$ for $30-$ $120 \mathrm{~min}$ ), or (-)-U50488H (a selective $\kappa$-agonist, $1-10 \mathrm{mg} /$ $\mathrm{kg}$, i.p., $1 \mathrm{~h}$, or $10 \mathrm{mg} / \mathrm{kg}$ for $30-120 \mathrm{~min}$ ). To assess the specificity of the opioid receptor involved, groups of rats received single doses of the nonselective antagonist naloxone $(10 \mathrm{mg} / \mathrm{kg}$, i.p.) alone $(90 \mathrm{~min})$ or $60 \mathrm{~min}$ before sufentanil $(15 \mu \mathrm{g} / \mathrm{kg})$, the selective $\delta$-antagonist naltrindole $(5 \mathrm{mg} / \mathrm{kg}$, i.p.) alone $(60 \mathrm{~min})$ or $30 \mathrm{~min}$ before SNC-80 $(10 \mathrm{mg} / \mathrm{kg})$, and the selective $\kappa$-antagonist nor-binaltorphimine $(5 \mathrm{mg} / \mathrm{kg}$, i.p. $)$ alone $(90 \mathrm{~min})$ or $30 \mathrm{~min}$ before (-)$\mathrm{U} 50488 \mathrm{H}(10 \mathrm{mg} / \mathrm{kg})$. Control rats received $0.9 \%$ saline vehicle $(1 \mathrm{ml} / \mathrm{kg}$ ) or dimethyl sulfoxide (DMSO, $1 \mathrm{ml} / \mathrm{kg}$, in the case of SNC-80). The animals were killed by decapitation at the indicated times. For the chronic treatment with morphine, the rats were injected i.p. three times daily during 5 days with increasing doses of the opiate (10$100 \mathrm{mg} / \mathrm{kg}$ ) (Boronat et al, 2001) and killed $2 \mathrm{~h}$ after the last dose. After this chronic treatment, naloxone $(2 \mathrm{mg} / \mathrm{kg}$, i.p., $2 \mathrm{~h}$ )-precipitated withdrawal or spontaneous ( 24 and $48 \mathrm{~h}$ ) opiate withdrawal was induced, which resulted in the standard behavioral reaction (data not shown; see Gabilondo and García-Sevilla, 1995; Miralles et al, 2005). In another series of chronic experiments, groups of rats were treated with SNC-80 $(10 \mathrm{mg} / \mathrm{kg})$ or $(-)-\mathrm{U} 50488 \mathrm{H}$ $(10 \mathrm{mg} / \mathrm{kg})$ once daily during 5 days. After these chronic treatments, naltrindole or nor-binaltorphimine $(5 \mathrm{mg} / \mathrm{kg}$, i.p., $2 \mathrm{~h}$ )-precipitated opiate withdrawal was induced, which resulted in a mild behavioral $(\kappa)$ reaction or the absence of behavioral $(\delta)$ signs (data not shown; see Milanés and Laorden, 1998; Brandt et al, 2001). Control rats received chronic $0.9 \%$ saline $(1 \mathrm{ml} / \mathrm{kg})$ or DMSO $(1 \mathrm{ml} / \mathrm{kg}$, in the case of SNC-80) in parallel. The animals were killed $30 \mathrm{~min}-2 \mathrm{~h}$ after the last dose (chronic saline, chronic opiate, or chronic opiate plus withdrawal) or at the times indicated after morphine withdrawal. In a final series of experiments, groups of rats received a single i.p. injection of the cannabinoid $\mathrm{CB}_{1}$ receptor agonist WIN55,212-2 (4 and $8 \mathrm{mg} / \mathrm{kg}, 1 \mathrm{~h}$ ) or were treated twice daily (i.p.) during 5 days with increasing doses of this agonist $(2-8 \mathrm{mg} / \mathrm{kg}$; rats killed $1 \mathrm{~h}$ after the last dose). Control rats received the appropriate vehicle (cremophor EL: ethanol: water; $1: 1: 18,1 \mathrm{ml} / \mathrm{kg}$ i.p.) (see Moranta et al, 2004). The brains were rapidly removed and specimens of the cerebral cortex and/or corpus striatum were dissected on ice, frozen in liquid nitrogen, and then stored at $-80^{\circ} \mathrm{C}$ until use.

\section{In Vivo Effect of MEK Inhibition on $\delta$-Opioid Receptor-Mediated Changes in FADD and MEK/ERK Activities}

To assess the possible involvement of MAPK/ERK1/2 in the regulation of FADD by the $\delta$-agonist SNC-80, groups of rats were treated with the highly selective MAP/ERK kinases (MEK1/2) inhibitor SL 327 (Scherle et al, 2000) $(20 \mathrm{mg} / \mathrm{kg}$, i.p.) alone $(90 \mathrm{~min})$ or $60 \mathrm{~min}$ before SNC-80 $(10 \mathrm{mg} / \mathrm{kg}$, $30 \mathrm{~min})$ to block ERK1/2 activation. Control rats received DMSO $(1 \mathrm{ml} / \mathrm{kg})$ or SNC-80 $(10 \mathrm{mg} / \mathrm{kg}$, i.p., $30 \mathrm{~min})$. The animals were killed at the indicated times and the immunodensity of FADD quantitated. In this series of experiments, the effects of SNC-80, SL 327, and SNC + SL on the contents of MEK/ERK, Fas receptor proteins, and $\beta$ actin were also quantitated (see below). In the MEK/ERK1/2 activation assays, equal amounts of protein were used to visualize and quantify phosphorylation of MEK1/2 and ERK1/2 (p44/42 MAP kinases) by immunoblotting essentially as described (Ferrer-Alcón et al, 2004).

\section{Sample Preparations, Protein Dephosphorylation and Subcellular Fractionation Experiments}

Brain tissue was homogenized $(1: 15, \mathrm{wt} / \mathrm{vol})$ in cold $50 \mathrm{mM}$ Tris-HCl buffer, $\mathrm{pH} 6.8$, containing $2 \%$ SDS, 1 mM EDTA, 
and various protease inhibitors (García-Fuster et al, 2003a). Aliquots of total homogenate were mixed with equal volumes of electrophoresis loading buffer, boiled (denatured), and stored at $-20^{\circ} \mathrm{C}$ until use. Protein concentrations were determined by the BCA Protein Assay Reagent (Pierce Biotechnology). In addition to rat brain, mouse (cerebral cortex) and human (prefrontal cortex) brain samples were also used for the immunodetection and characterization of FADD with different anti-FADD antibodies. In some experiments, the specificity of the anti-FADD antibody (H-181) for nonphosphorylated or phosphorylated epitopes was tested on Western blots of rat brain, essentially as described (Ferrer-Alcón et al, 2000). Briefly, brain tissue was homogenized (as above without EDTA) and centrifuged (40000 $\times g$ for $15 \mathrm{~min})$. Aliquots of the initial homogenate $(\mathrm{H})$ and the final supernatant (S2) were incubated in the absence (control) or presence of calf intestinal mucosa alkaline phosphatase (95 units, Product 79390, Sigma-Aldrich, Germany). Some samples containing the enzyme were also incubated with $100 \mathrm{mM}$ sodium pyrophosphate (inhibited control). The reaction was terminated by adding $100 \mathrm{mM}$ sodium pyrophosphate to control and alkaline phosphatase samples. Finally, the samples were prepared (about $40 \mu$ g protein) for SDS-PAGE and FADD immunodetection (see below). In other experiments the subcellular localization of FADD was monitored (cerebral cortex, $100 \mathrm{mg}$ ) using the Subcellular Proteome Extraction Kit (ProteoExtract ${ }^{\mathrm{TM}}$, Calbiochem, Germany) following the manufacturer's instructions. This method is based on the different solubility of proteins in certain subcellular compartments to yield four subproteomes enriched in cytosolic (F1), membrane/organelle (F2), nuclear (F3), and cytoskeletal proteins (F4) (AbdolzadeBavil et al, 2004), and this procedure was also used to assess the effect of sufentanil on the content of FADD in the different compartments by Western blot analysis $(15 \mu \mathrm{g}$ protein), as described below.

\section{Immunoblot Assays and Quantitation of Target Proteins}

In routine experiments, $40 \mu \mathrm{g}$ protein of each rat brain sample was subjected to SDS-PAGE on $10 \%$ (FADD) or $15 \%$ (caspases) polyacrylamide minigels (Bio-Rad Laboratories, Hercules, CA, USA). Proteins were electrophoretically transferred to nitrocellulose membranes and incubated in a blocking solution (García-Fuster et al, 2003a). The membranes were incubated overnight at $4{ }^{\circ} \mathrm{C}$ in blocking solution containing the appropriate primary antibody: antiFADD (H-181) (affinity-purified rabbit polyclonal antibody raised against human FADD C-terminal 28-208 residues; dilution 1:5000; sc-5559, batch C-112, Santa Cruz Biotechnology, CA, USA), anti-FADD (rat) (purified mouse monoclonal antibody; dilution 1:1000; cat.: 558202, clone 28, batch 08738, BD Biosciences Pharmingen, San José, CA, USA), anti-FADD (human) (purified mouse monoclonal antibody; dilution 1:500; cat.: 610399, clone 1, BD Biosciences), anti-caspase- 8 p20 (rabbit polyclonal antibody raised against human caspase-8, residues $217-350$, that also reacts with the p20 cleavage form; dilution 1:1000; sc-7890, batch F-1604, Santa Cruz), anti-caspase-3 (rabbit polyclonal antibody raised against the full-length precursor form of human caspase-3, residues $1-277$, that also reacts with the p20 cleavage form; dilution $1: 2000$; sc-7148, batch $\mathrm{H}-011$, Santa Cruz), anti-caspase-3 (rabbit polyclonal antibody raised against the full-length precursor form of human caspase- 3 that also reacts with the p20 cleavage form; dilution $1: 1000$, cat.: 552785, batch 11136, BD Biosciences), anti- $\beta$-actin (mouse monoclonal antibody; clone AC-15, batch No. 014K4840; dilution 1: 10 000; Sigma Chemical Co., MO, USA), and anti-neurofilament-L (mouse monoclonal antibody; clone NR4, batch no. 109H4809; dilution $1: 5000$; Sigma). In order to test the selectivity of anti-FADD H-181 antibody with specific proteins, the antigenic peptide (sc4701, Santa Cruz) was preincubated in excess with the antiserum to block the binding of the antibody to the specific protein species tested. Other primary antibodies used were: anti-Fas M-20 (Santa Cruz); anti-total and antiphosphorylated MEK1/2 (Cell Signaling Technology, Beverly, MA, USA), and anti-total and anti-phoshorylated ERK1/2 (Calbiochem-Novabiochem Corporation, San Diego, CA, USA) (see García-Fuster et al, 2003a; Ferrer-Alcón et al, 2004). The secondary antibody, horseradish peroxidase-linked anti-rabbit or anti-mouse IgG, was incubated at $1: 5000$ dilution in blocking solution at room temperature for $1 \mathrm{~h}$, or during $45 \mathrm{~min}$ for the anti-goat IgG. Immunoreactivity of target proteins was detected with the Enhanced Chemiluminiscence (ECL) Western Blot Detection system (Amersham International, Buckinghamshire, UK) and visualized by exposure to Hyperfilm ECL film (Amersham) for $30 \mathrm{~s}-60 \mathrm{~min}$ (autoradiograms). The autoradiograms were quantitated by densitometric scanning (GS-800 Imaging Densitometer, Bio-Rad). The amount of target proteins in brain samples of rats treated with opiate drugs was compared in the same gel with that of control rats which received saline or DMSO solution. Experiments were performed by using protein samples known to be within the linear range for immunolabeling of FADD and other target proteins (see Boronat et al, 2001). The quantification procedure was assessed 3-5 times in different gels (each gel with different brain samples from saline/DMSO- and drugtreated rats). Finally, percent changes in immunoreactivity with respect to control samples (100\%) were calculated for each rat treated with the specific drug in the various gels and the mean value used as a final estimate. In all experiments, the content of $\beta$-actin (a cytoskeletal protein not altered by opiate treatment; Ammon et al, 2003; MarieClaire et al, 2004) was quantitated as a negative control.

\section{Data Analyses and Statistics}

All series of data were analyzed with the program GraphPad Prism $^{\mathrm{TM}}$, version 3.0. Results are expressed as mean values \pm standard error of the mean (SEM). One-way ANOVA followed by Bonferroni's multiple comparison test and Student's two-tailed $t$-test were used for the statistical evaluations. The level of significance was chosen as $p<0.05$.

\section{Drugs and Chemicals}

Opiate drugs (and their sources) included sufentanil $\mathrm{HCl}$ (Janssen-Cylag, SA, Madrid, Spain), morphine $\mathrm{HCl}$ and heroin $\mathrm{HCl}$ (Unión Químico-Farmacéutica SAE, Madrid, Spain), ( + )-4-[( $\alpha R)-\alpha-(2 S, 5 R)-4$-allyl-2,5-dimethyl-1-piperazinyl)-3-methoxybenzyl]- $N$ - $N$, diethylbenzamide SNC-80, 
$1 S$-trans)-3,4-dichloro- $N$-methyl- $N$-[2-(1-pyrrolidinyl)cyclohexyl]-benzeneacetamide (-)-U-50488- $\mathrm{HCl}$, naloxone $\mathrm{HCl}$, naltrindole $\mathrm{HCl}$, and nor-binaltorphimine $\mathrm{HCl}$ (Tocris Cookson Ltd, Avonmouth, UK). (R)-(+)-[2,3-dihydro5-methyl-3-(4-morpholinylmethyl)pyrrolo[1,2,3-de]-1,4benzoxazin-6-yl]-1-naphtalenyl-methanone mesylate (WIN $55,212-2)$ and the compound $\alpha$-amino-(4-aminophenylthio)-methylene-2-(trifluoromethyl)-benzeneacetonitrile (SL 327) were purchased from Tocris. Acrylamide (Protogel) was from Conda, SA, Madrid, Spain. The ProteoExtract ${ }^{\mathrm{TM}}$ Subcellular Proteome Extraction Kit was from Calbiochem, Merck Biosciences, Darmstadt, Germany. Other materials such as the secondary antibodies, ECL reagents, and autoradiography films were purchased from Amersham International (UK) or Santa Cruz Biotechnology (USA). All other chemicals were from Sigma Chemical.

\section{RESULTS \\ Immunodetection and Subcellular Localization of FADD in Brain Tissue}

In Western blot analyses, the antibody $\mathrm{H}-181$ (mapping at the FADD C-terminal) recognized various closely migrating bands with sizes of about $51-75 \mathrm{kDa}$ from rat, mouse, and human brain (total homogenate), which represented specific FADD forms since they were not immunodetected with the preabsorbed antibody (Figure 1a). Similar results were obtained with two monoclonal antibodies (Figure $1 \mathrm{~b}, \mathrm{c})$, which also immunodetected the $51-\mathrm{kDa}$ form of FADD in rat brain tissue, but with a weak signal that was difficult to quantitate in routine experiments. In human brain tissue, the anti-human monoclonal antibody also detected a peptide of about $25-\mathrm{kDa}$ that corresponded to
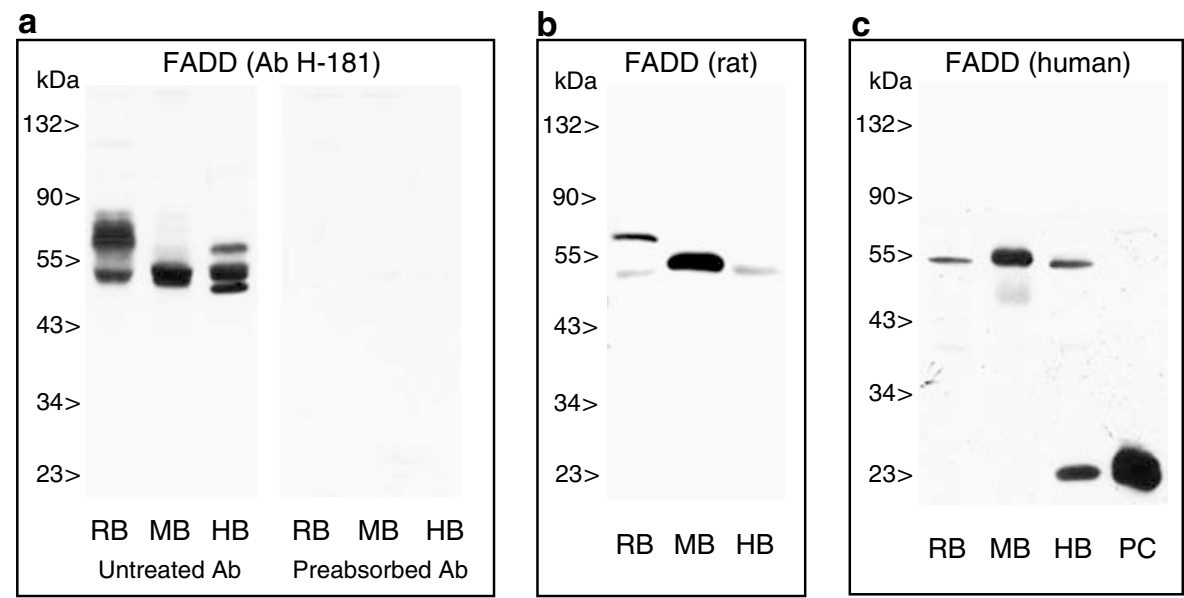

d

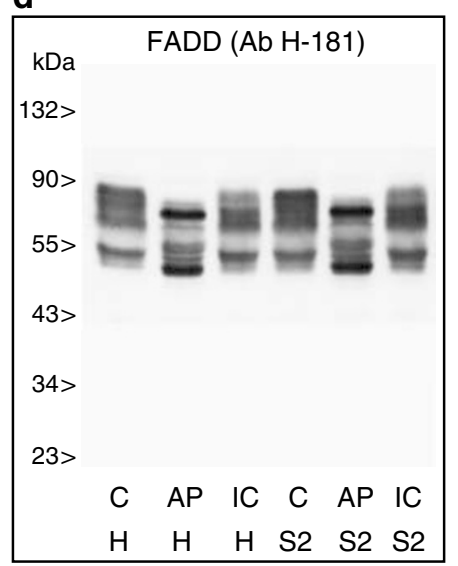

e

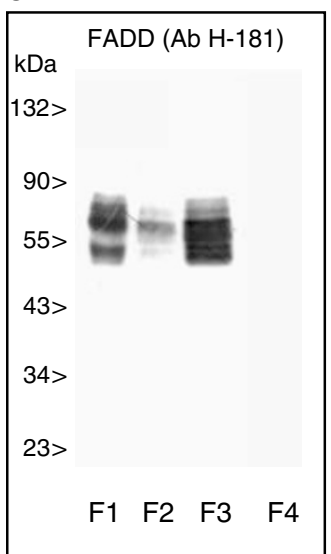

Figure I $(a-c)$ Representative autoradiograms of Western blots depicting labeling of immunodetectable FADD ( $\approx 5 \mathrm{I}-75 \mathrm{kDa}$ forms) with the polyclonal antibody $\mathrm{H}-\mid \mathrm{BI}$ (a) and two monoclonal antibodies (b, c) in rat brain (RB, cerebral cortex), mouse brain (MB, cerebral cortex), and human brain (HB, prefrontal cortex). Samples: $40 \mu \mathrm{g}$ protein of total homogenate. PC: positive control (human epidermoid carcinoma cell line). The specificity of antibody HI8I was assessed by preincubation with its antigenic peptide (preabsorbed antibody), which resulted in the blockade of protein immunoreaction. (d) Representative immunoblot for the effect of dephosphorylation with alkaline phosphatase on FADD immunoreactivity in rat brain. Brain tissue (H: total homogenate; S2: cytosolic fraction) was incubated at $30^{\circ} \mathrm{C}$ for $15 \mathrm{~min}$ in the absence (C, control samples) or presence of alkaline phosphatase (AP, 95 units). Samples containing the enzyme were also incubated with $100 \mathrm{mM}$ sodium pyrophosphate (IC, inhibited controls). The amount of protein loaded on the gel was $40 \mu \mathrm{g}$ for all samples. Note that FADD dephosphorylation did not block the immunoreactivity of antibody $\mathrm{H}$ - I 8 I (ie the antibody reacted with FADD independently of the state of protein phosphorylation). (e) Representative immunoblot depicting the subcellular localization of FADD in the rat cerebral cortex (FI: cytosol; F2: membrane/organelle; F3: nucleus; F4: cytoskeletal proteins; I 5 ug protein for each fraction) (Subcellular Proteome Extraction Kit, ProteoExtract ${ }^{\mathrm{TM}}$ ). Note that FADD was mainly expressed in FI and F3 and that the protein was not detected in the F4. The apparent molecular masses of FADD forms were determined by calibrating the blots with prestained molecular weight markers as shown on the left-hand side. In each experiment, all samples were run in the same gel. 
FADD monomer (identified with a positive control) (Figure 1c). On the other hand, the enzymatic dephosphorylation of FADD with alkaline phosphatase (total homogenate and cytosolic fraction) increased the reactivity of some bands and induced an apparent change in the protein $\mathrm{Mr}$ shifting its mobility (51- and $75-\mathrm{kDa}$ forms), indicating that antibody $\mathrm{H}-181$ reacted with FADD independently of the state of protein phosphorylation (Figure 1d). These results indicated that in brain tissue FADD also has the ability to aggregate (see Siegel et al, 2000), being mainly expressed as a homo-dimer/trimer. In rat brain (cerebral cortex) and at the subcellular level, FADD was abundantly localized in the cytosol and nucleus and to a lesser extent in membranes, and it was not detected in the cytoskeletal compartment (Figures 1e and 3). From these preliminary experiments, the effects of opiate drugs on $51 \mathrm{kDa}$ FADD (antibody $\mathrm{H}-181$ ) were assessed in the total homogenate of rat brain tissue, except for those of sufentanil that were also quantitated in the different subcellular compartments.

\section{Acute Effects of Opiate Drugs on FADD Immunoreactivity in Rat Brain}

The acute treatment with sufentanil (a potent $\mu$-opioid receptor agonist; $1-30 \mu \mathrm{g} / \mathrm{kg}$, s.c., $30 \mathrm{~min}$ ), compared with vehicle solution administration, induced modest increases $(12-22 \%, p>0.05$, at low doses) or marked decreases (40$58 \%, p<0.01$, at high doses) in the immunodensity of FADD in the rat cerebral cortex (total homogenate) (Figure 2a), with a rapid time-course that lasted for about 60 min (Figure 2b). A similar reduction of FADD $(51 \mathrm{kDa})$ content induced by sufentanil $(15 \mu \mathrm{g} / \mathrm{kg})$ was quantitated in the cortex $(30-35 \%)$ when a monoclonal antibody (see Figure 1c) was used as a tool (data not shown). At the subcellular level, sufentanil $(15 \mu \mathrm{g} / \mathrm{kg})$ decreased the content of FADD in the cytosolic (71\%) and nuclear (31\%) fractions
(Figure 3), indicating that the changes of this protein quantitated in the total homogenate of the cerebral cortex reflected its regulation in the key cellular compartments.

Similarly to sufentanil, acute morphine $(3-100 \mathrm{mg} / \mathrm{kg}$, i.p., $2 \mathrm{~h})$ also induced bell-shaped dose effects with increases $(20-42 \%, \quad p<0.01 ; 10-30 \mathrm{mg} / \mathrm{kg})$ and decreases $(29 \%$, $p<0.05 ; 100 \mathrm{mg} / \mathrm{kg}$ ) in FADD density in the cortex (Figure 4a). Acute heroin (10 mg/kg, i.p., $2 \mathrm{~h}$ ) also augmented FADD content in the same brain region $(37 \pm 4 \%, n=5, p=0.002)$ (data not shown). Pretreatment of rats with naloxone $(10 \mathrm{mg} / \mathrm{kg})$ fully prevented the acute inhibition of FADD induced by $15 \mu \mathrm{g} / \mathrm{kg}$ sufentanil (Figure 2c).
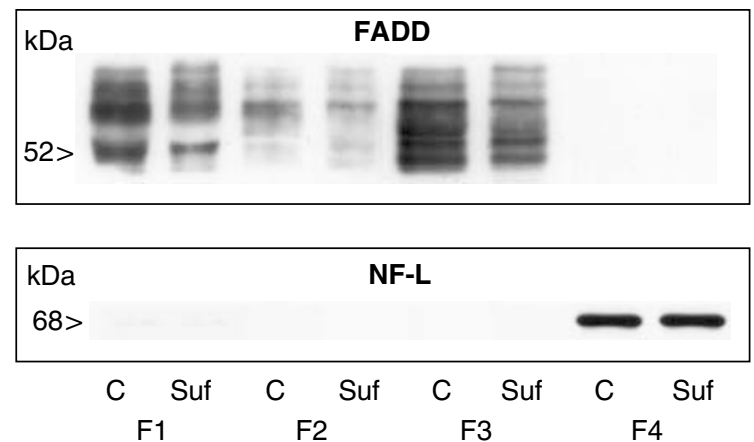

Figure 3 Acute effect of sufentanil ( $15 \mu \mathrm{g} / \mathrm{kg}$, s.c., $30 \mathrm{~min}$ ) on FADD (5 I$\mathrm{kDa}$ ) immunodensity in various subcellular compartments of the rat cerebral cortex (see Figure le for other details). Samples: $15 \mu \mathrm{g}$ protein. Note that sufentanil decreased FADD content in the cytosolic (FI: by 7I\%) and nuclear (F3: by 32\%) fractions. In the membrane/organelle fraction (F2), the weak signal of FADD was difficult to quantitate. In the cytoskeletal fraction (F4) FADD was not immunodetected. Bottom: immunoblots of neurofilament (NF-L) proteins in FI-F4. Note that NF-L was immunodetected in F4 but not in the other subcellular fractions. The apparent molecular masses of FADD and NF-L were determined by calibrating the blots with prestained molecular weight markers as shown on the left-hand side. The experiment was repeated three times with similar results.
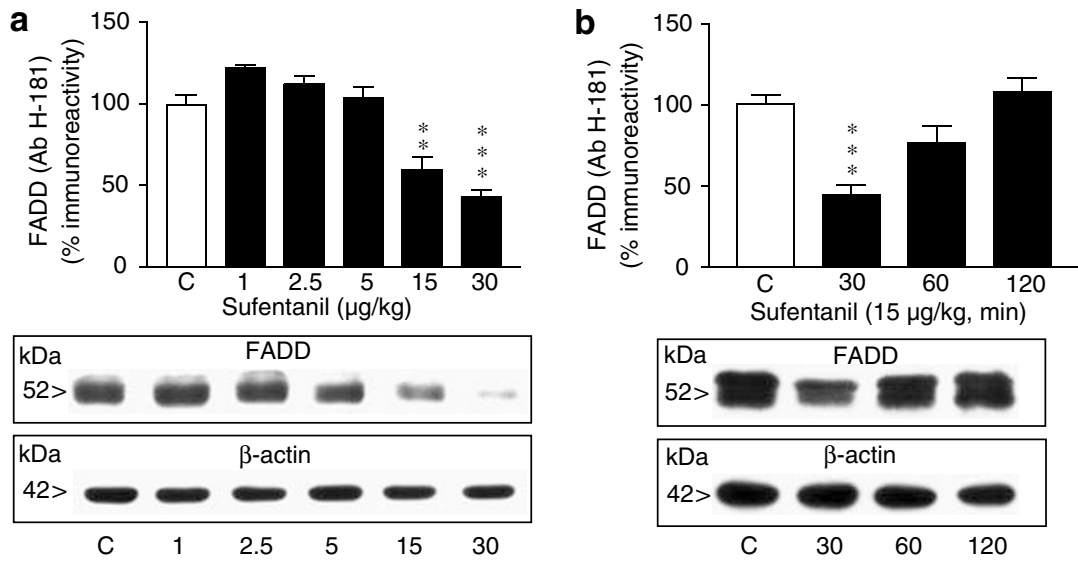

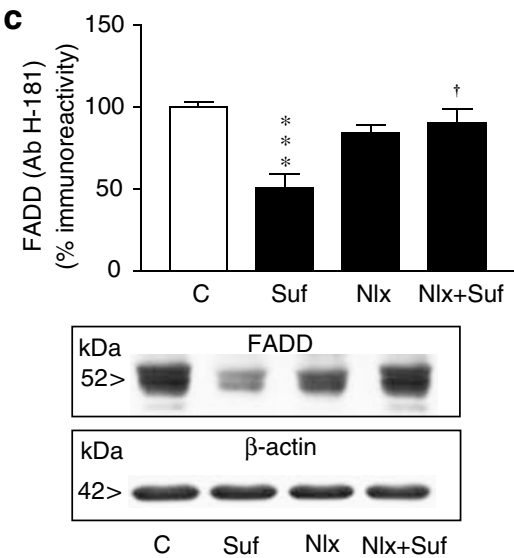

Figure 2 Acute effects of sufentanil on FADD immunodensity in rat brain (cerebral cortex). (a) Dose-response effects. Groups of treatments: saline (C, $n=6)$, sufentanil $(1-30 \mu \mathrm{g} / \mathrm{kg}$, s.c., $30 \mathrm{~min} ; n=3-4)$. Columns are means \pm SEM of $n$ experiments per group with an animal per experiment, and expressed as percentage of saline-treated rats. One-way ANOVA detected a significant difference between the groups of treatments $(F(5, \mid 8)=23.8, p<0.000 I)$. ${ }^{*}{ }^{*} p<0.01$; *** $p<0.00$ I when compared with the saline group (ANOVA followed by Bonferroni's test). (b) Time-course ( $\left.0-120 \mathrm{~min}\right)$ effects ( $15 \mu \mathrm{g} / \mathrm{kg}$; $n=4-8)$. Other details as above. ANOVA $(F(3,16)=|4.3, p<0.000|$ ): ***** $p<0.000$ I vs control. (c) Antagonism by naloxone. Groups of treatments: saline $(\mathrm{C}, n=6)$, sufentanil (Suf, $15 \mu \mathrm{g} / \mathrm{kg}, 30 \mathrm{~min} ; n=5)$, naloxone (NIx, $10 \mathrm{mg} / \mathrm{kg}$, i.p., $90 \mathrm{~min} ; n=4)$ and $\mathrm{NIx}+\mathrm{Suf}(n=5)$. Other details as above. ANOVA $(F(3,16)=11.5, p<0.005)$ : **** $p<0.000$ I vs control; ${ }^{\dagger} p<0.0$ I vs sufentanil. Bottom (a-c): representative immunoblots of FADD for each set of experiments, and the corresponding for $\beta$-actin as a loading control (sample: $40 \mu \mathrm{g}$ protein). 

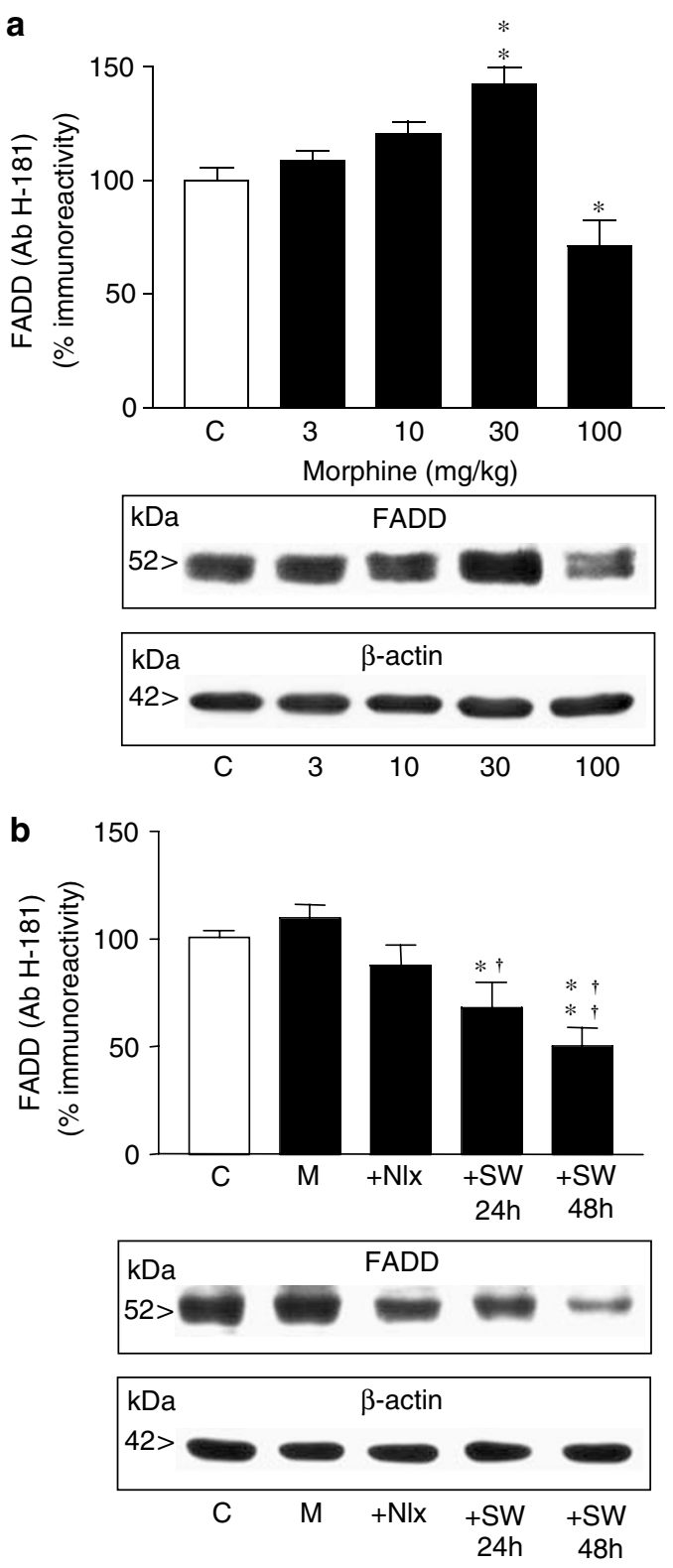

Figure 4 Acute, chronic, and withdrawal effects of morphine on FADD immunodensity in rat brain (cerebral cortex). (a) Acute dose-response effects. Groups of treatments: saline $(C, n=6)$, morphine $(3-100 \mathrm{mg} / \mathrm{kg}$, i.p., 2 h; $n=4-5$ ). Columns are means \pm SEM of $n$ experiments per group with an animal per experiment, and expressed as percentage of salinetreated rats. One-way ANOVA detected a significant difference between the groups of treatments $(F(4,19)=\mid 2.2, p<0.000 I)$ : $* p<0.05$; $* * p<0.0$ I when compared with the saline group (ANOVA followed by Bonferroni's test). (b) Chronic effects of saline (C, $n=9)$ and morphine (M, I0-100 mg/ $\mathrm{kg}$ for 5 days; $n=9)$ followed by naloxone $(\mathrm{Nlx}, 2 \mathrm{mg} / \mathrm{kg}$, i.p.; $n=9)$ precipitated ( $2 \mathrm{~h}$ ) or spontaneous (SW, 24 and $48 \mathrm{~h} ; n=4-5)$ opiate withdrawal. Other details as above. ANOVA $(F(4,31)=7.3, p<0.005)$ : ${ }^{*} p<0.05$; ${ }^{*} p<0.0$ I vs chronic saline; ${ }^{\dagger} p<0.05,{ }^{\dagger \dagger} p<0.00$ I vs chronic morphine. Bottom $(a, b)$ : representative immunoblots of FADD for each set of experiments, and the corresponding for $\beta$-actin as a loading control (sample: $40 \mu \mathrm{g}$ protein)

The acute treatment with SNC-80 (a selective $\delta$-agonist; $10 \mathrm{mg} / \mathrm{kg}$, i.p., $30 \mathrm{~min}$ ) decreased the immunodensity of FADD in the cortex $(56 \%, p<0.001)$ for more than $1 \mathrm{~h}$ (Figure $5 \mathrm{a}, \mathrm{b}$ ), and this effect was antagonized by the

selective $\delta$-antagonist naltrindole $(5 \mathrm{mg} / \mathrm{kg})$ (Figure $5 \mathrm{c}$ ). Treatment with U50488H (a selective $\kappa$-agonist; $10 \mathrm{mg} / \mathrm{kg}$, i.p., $1 \mathrm{~h})$ also reduced FADD content in the cortex $(36 \%$, $p<0.001)$ and the effect lasted for more than $2 \mathrm{~h}(57 \%$, $p<0.0001$ ) (Figure 6a, b). This inhibitory effect of U50488H on FADD was blocked by the selective $\kappa$-antagonist norbinaltorphimine $(5 \mathrm{mg} / \mathrm{kg}$ ) (Figure $6 \mathrm{c})$. Lower doses of SNC80 and $\mathrm{U} 50488 \mathrm{H}$ ( 1 and $3 \mathrm{mg} / \mathrm{kg}$ ) did not alter the content of FADD in the brain (Figures $5 a$ and $6 a$ ).

\section{Effects of Chronic Opiate Drugs, and of Antagonist-Precipitated or Natural Opiate Withdrawal on FADD Immunoreactivity in Rat Brain}

Chronic (5 days) treatment with morphine (10-100 mg/kg), compared with saline solution administration, did not alter significantly the immunodensity of FADD in the cerebral cortex ( $2 \mathrm{~h}$ post-treatment) (Figure $4 \mathrm{~b}$ ), indicating the induction of a marked tachyphylaxis to the repeated doses of the opiate. In morphine-dependent rats, naloxone $(2 \mathrm{mg} / \mathrm{kg})$-precipitated withdrawal $(2 \mathrm{~h})$ induced a modest decrease in the density of FADD $(13 \%, p>0.05)$, but the spontaneous opiate withdrawal ( 24 and $48 \mathrm{~h}$ ) was associated with a marked and time-dependent downregulation of FADD content in the cortex ( 32 and $50 \%$, respectively, $p<0.05$ ) (Figure $4 \mathrm{~b}$ ).

The repeated treatment (5 days) with SNC-80 (10 mg/kg) or $\mathrm{U} 50488 \mathrm{H}(10 \mathrm{mg} / \mathrm{kg})$, compared with the corresponding vehicle, did not modify the density of FADD in the cortex (Figures $5 \mathrm{~d}$ and $6 \mathrm{~d}$ ), which also suggested the induction of tachyphylaxis to the acute effects of the opiates on this protein. In SNC-80-dependent rats, naltrindole $(2 \mathrm{mg} / \mathrm{kg})$ precipitated withdrawal $(2 \mathrm{~h})$ induced a significant reduction of FADD content in the cortex $(35 \%, p<0.05)$ (Figure 5d). In U50488H-dependent rats, nor-binaltorphimine $(2 \mathrm{mg} / \mathrm{kg})$-precipitated withdrawal $(2 \mathrm{~h})$ did not induce significant changes in the density of FADD in the cortex (Figure 6d).

The various opiate treatments (acute, chronic, and withdrawal effects) did not alter significantly the immunodensity of $\beta$-actin, which was used as a negative control (see figures).

\section{Effect of MEK Inhibition on $\delta$-Agonist-Induced Downregulation of FADD in Rat Brain}

The highly selective MEK1/2 inhibitor, SL 327, was used as a tool to assess the possible involvement of ERK1/2 activation in the in vivo regulation of FADD by the selective $\delta$-agonist SNC-80 (Figure 7). The $\delta$-opioid receptor was chosen as a target because it appears to regulate the expression of FADD (tonic inhibition) in the brain (see Discussion).

Pretreatment of rats with SL $327(20 \mathrm{mg} / \mathrm{kg}$, i.p.) fully prevented the downregulation of FADD content induced by SNC-80 $(10 \mathrm{mg} / \mathrm{kg}, 30 \mathrm{~min})$ both in the cerebral cortex (decrease: $43 \%, p<0.05$ ) and corpus striatum (decrease: $29 \%, p<0.05)$ (Figure 7a,b). SL 327 (90 min) alone did not alter the density of FADD (Figure $7 \mathrm{a}, \mathrm{b}$ ). In both brain regions, SL 327 by itself reduced, as expected, the basal activity of phosphorylated ERK1/2 (p44/42 MAP kinases, $15-46 \%, p<0.05)$ and augmented that of phosphorylated MEK1/2 (70-109\%, $p<0.01)$ (this latter effect was probably 

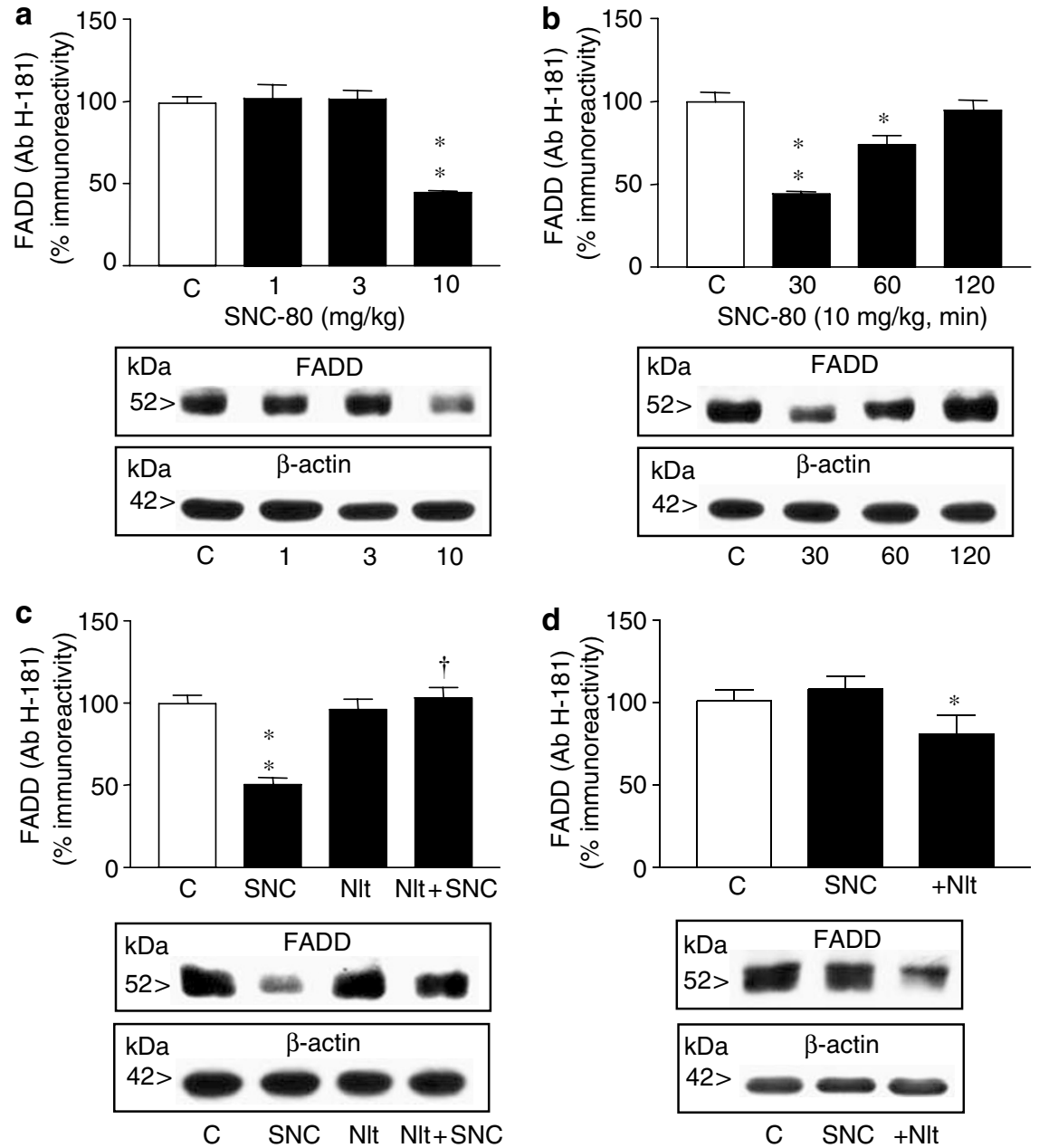

Figure 5 Acute, chronic, and withdrawal effects of SNC-80 (a selective $\delta$-opioid receptor agonist) on FADD immunodensity in rat brain (cerebral cortex). (a) Acute dose-response effects. Groups of treatments: saline (C, $n=10)$, SNC-80 ( $1-10$ mg/ $/ \mathrm{kg}$, i.p., 30 min; $n=4-5)$. Columns are means \pm SEM of $n$ experiments per group with an animal per experiment, and expressed as percentage of saline-treated rats. One-way ANOVA detected a significant difference between the groups of treatments $(F(3,20)=21.5, p<0.0001)$ : *** $p<0.00$ I when compared with the saline group (ANOVA followed by Bonferroni's test). (b) Time-course (30-I20 min) effects $(10 \mathrm{mg} / \mathrm{kg} ; n=4-6)$. Other details as above. ANOVA $(F(3, I 4)=22.5, p<0.000 I)$ : ${ }^{*} p<0.05$, *** $p<0.001$ vs control. (c) Antagonism by naltrindole ( $\delta$-selective). Groups of treatments: saline (C, $\left.n=4\right), \quad$ SNC-80 (SNC, I0 mg/kg, $30 \mathrm{~min} ; n=7)$, naltrindole (NIt, $5 \mathrm{mg} / \mathrm{kg}$ i.p., $60 \mathrm{~min} ; n=3)$ and NIt $+\mathrm{SNC}(n=5)$. Other details as above. ANOVA $(F(3, I 5)=26.5, p<0.00 \mathrm{I})$ : *** $p<0.00 \mathrm{I}$ vs control; ${ }^{\dagger} p<0.001$ vs SNC-80. (d) Chronic effects of saline (C, $\left.n=8\right)$ and SNC-80 (SNC, $10 \mathrm{mg} / \mathrm{kg}$ for 5 days; $\left.n=5\right)$ followed by naltrindole (NIt, $5 \mathrm{mg} / \mathrm{kg}$, i.p.)-precipitated $(2 \mathrm{~h})$ opiate withdrawal $(n=4)$. Other details as above. ANOVA $(F(2, \mid 4)=5.5, p<0.05)$ : * $p<0.05$ vs chronic SNC-80. Bottom (a-d): representative immunoblots of FADD for each set of experiments, and the corresponding for $\beta$-actin as a loading control (sample: $40 \mu \mathrm{g}$ protein).

mediated by an intra-cascade feedback regulation; see Kolch et al, 2005; Vogel et al, 2005), without altering the total content of MEK/ERK proteins (Figure 7c,d). Moreover, SNC-80 increased the phosphorylation of MEK1/2 (150$160 \%, p<0.01)$ and ERK1/2 $(31-51 \%, p<0.05)$, and pretreatment with SL 327, consequently, blocked the activation of ERK1/2, but not that of MEK1/2 induced by the $\delta$-agonist (Figure 7c,d). In these series of experiments, the content of $\beta$-actin remained unchanged after the various treatments (Figure 7a,b).

The inhibition of ERK/MAPK cascade with SL 327 did not alter significantly the abundance of Fas proteins (receptor glycosylated forms and complexes of Fas monomers) (data not shown), excluding alterations in Fas receptor expression as a mechanism behind the reported regulation of FADD in the brain.
Acute, Chronic, and Withdrawal Effects of Opiate Drugs on Caspase-8 and Caspase-3 Immunoreactivities in Rat Brain

The various acute and chronic treatments with opiate drugs ( $\mu$-, $\delta$-, and $\kappa$-agonists) and the induced opiate withdrawals did not modify significantly the immunodensities of the proforms of caspase- $8(55 \mathrm{kDa})$ and caspase-3 $(32 \mathrm{kDa})$ in the cerebral cortex (Table 1 and Figure 8). Moreover, the basal activation and cleavage of caspase-8 (human) and caspase-3 (rat) (about p20 kDa cleavage forms) were not altered by any opiate treatment or withdrawal state in the cortex (see Figure 8a, c for chronic morphine and opiate withdrawal). Another antibody used for the detection of caspase- 3 (human) only recognized the $32 \mathrm{kDa}$ proform in brain tissue (see Figure $8 \mathrm{~b}$ ). 

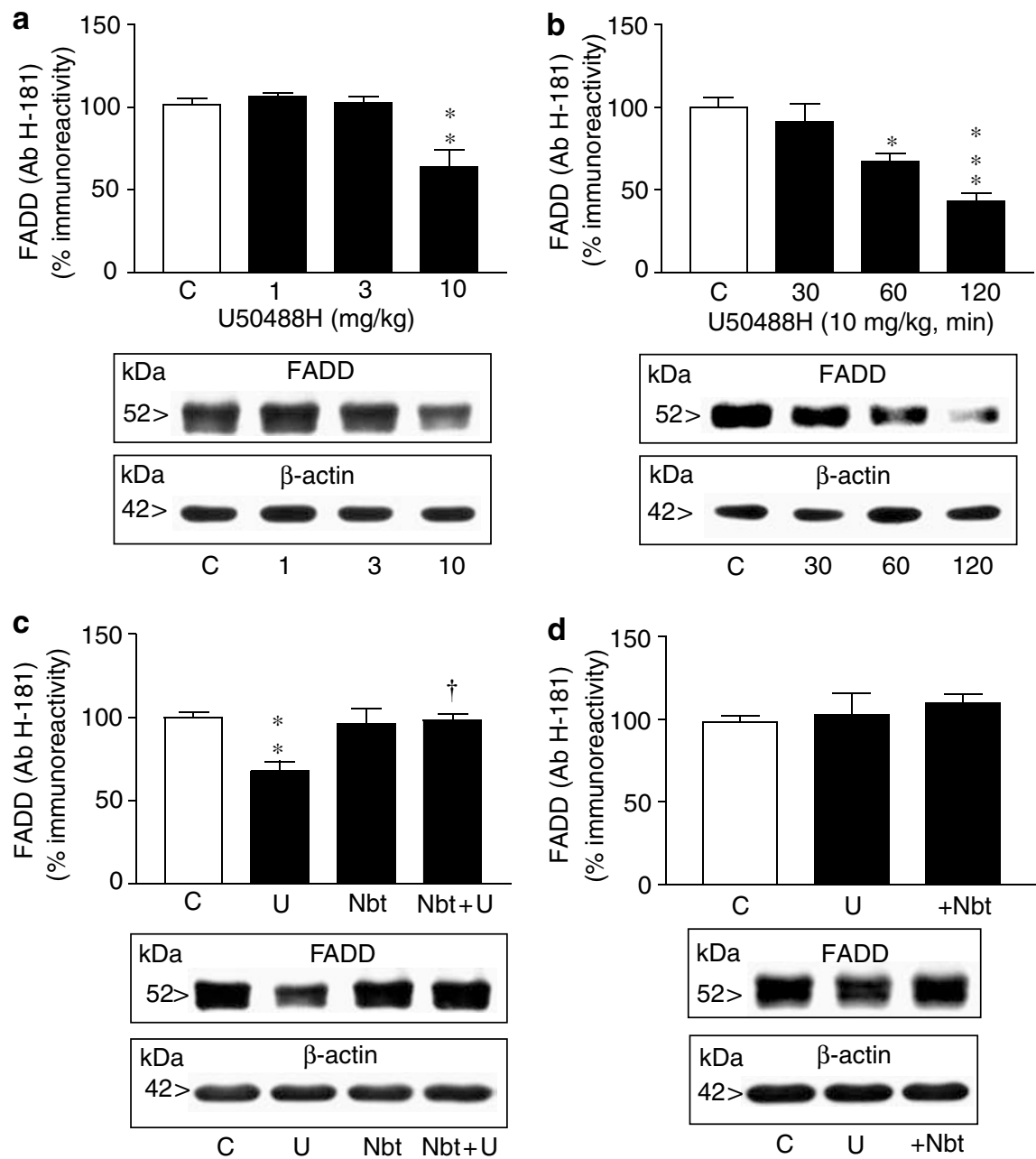

Figure 6 Acute, chronic, and withdrawal effects of $\mathrm{U} 50488 \mathrm{H}$ (a selective $\kappa$-opioid receptor agonist) on FADD immunodensity in rat brain (cerebral cortex). (a) Acute dose-response effects. Groups of treatments: saline $(C, n=7), U 50488 \mathrm{H}(I-10 \mathrm{mg} / \mathrm{kg}$, i.p., I h; $n=4)$. Columns are means \pm SEM of $n$ experiments per group with an animal per experiment, and expressed as percentage of saline-treated rats. One-way ANOVA detected a significant difference between the groups of treatments $(F(3,15)=11.2, p<0.0005)$ : ** $p<0.001$ when compared with the saline group (ANOVA followed by Bonferroni's test). (b) Time-course (30-120 min) effects $(10 \mathrm{mg} / \mathrm{kg} ; n=4-6)$. Other details as above. ANOVA $(F(3,14)=12.8, p<0.0005)$ : $* p<0.05$, **** $p<0.000$ I vs control. (c) Antagonism by nor-binaltorphimine ( $\kappa$-selective). Groups of treatments: saline $(\mathrm{C}, n=5), \cup 50488 \mathrm{H}(\mathrm{U}, 10 \mathrm{mg} / \mathrm{kg}, 60 \mathrm{~min}$; $n=4)$, nor-binaltorphimine (Nbt, $5 \mathrm{mg} / \mathrm{kg}$ i.p., $90 \mathrm{~min} ; n=4)$ and Nbt $+U(n=5)$. Other details as above. ANOVA $(F(3, \mid 4)=7.1, p<0.005)$ : $* * *<<0.00$ I vs control; ${ }^{\dagger} p<0.01$ vs $\cup 50488 \mathrm{H}$. (d) Chronic effects of saline $(\mathrm{C}, n=5)$ and $\cup 50488 \mathrm{H}(\mathrm{U}, 10 \mathrm{mg} / \mathrm{kg}$ for 5 days, $n=5)$ followed by nor-binaltorphimine (Nbt, $5 \mathrm{mg} / \mathrm{kg}$, i.p.)-precipitated $(2 \mathrm{~h})$ opiate withdrawal $(n=5)$. Other details as above. ANOVA did not detect a significant difference between the groups of treatments. Bottom (a-d): representative immunoblots of FADD for each set of experiments, and the corresponding for $\beta$-actin as a loading control (sample: $40 \mu \mathrm{g}$ protein)

\section{Acute and Chronic Effects of the Cannabinoid $\mathrm{CB}_{1}$ Receptor Agonist WIN 55,212-2 on FADD Immunoreactivity in Rat Brain}

To assess whether the stimulation of other inhibitory Gi/o protein-coupled receptors can induce a reduction of FADD in the rat brain, the effects of the cannabinoid $\mathrm{CB}_{1}$ receptor agonist WIN 55,212-2 were investigated. The $\mathrm{CB}_{1}$ receptor was chosen because this system, similarly to opiate drugs, has been associated with neurotoxicity and/or apoptosis through the modulation of MAPK pathways (see Downer et al, 2003; Powles et al, 2005).

The acute treatment of rats with high doses of WIN $55,212-2$ ( 4 and $8 \mathrm{mg} / \mathrm{kg}$, i.p., for $1 \mathrm{~h}$ ) or the repeated treatment with this agonist $(2-8 \mathrm{mg} / \mathrm{kg}$, i.p., for 5 days) (see Moranta et al, 2004) did not significantly alter the immunodensity of FADD in the cerebral cortex (Figure 9).

\section{DISCUSSION}

FADD protein in rat, mouse, and human brains was recognized as nonphosphorylated (faster-migrating) and phosphorylated (slower-migrating) species (see Zhang and Winoto, 1996; Scaffidi et al, 2000), indicating that the antibody H-181 (used for quantitative experiments) reacted with FADD independently of the state of protein phosphorylation. The relevance of the 51-kDa FADD form (antibody $\mathrm{H}-181$ ) was confirmed by use of two different monoclonal antibodies (cf. Figure 1b, c). Previous results (García-Fuster et al, 2003a) and the current data demonstrated that the 

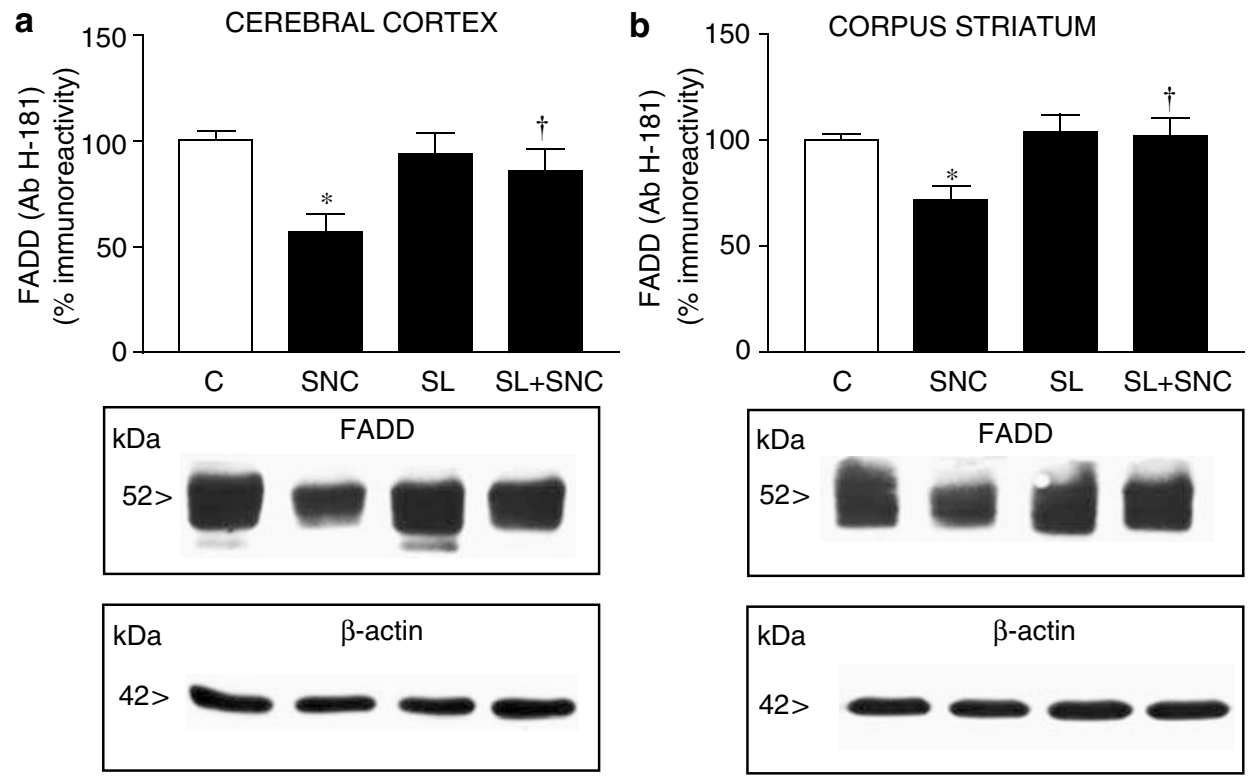

C
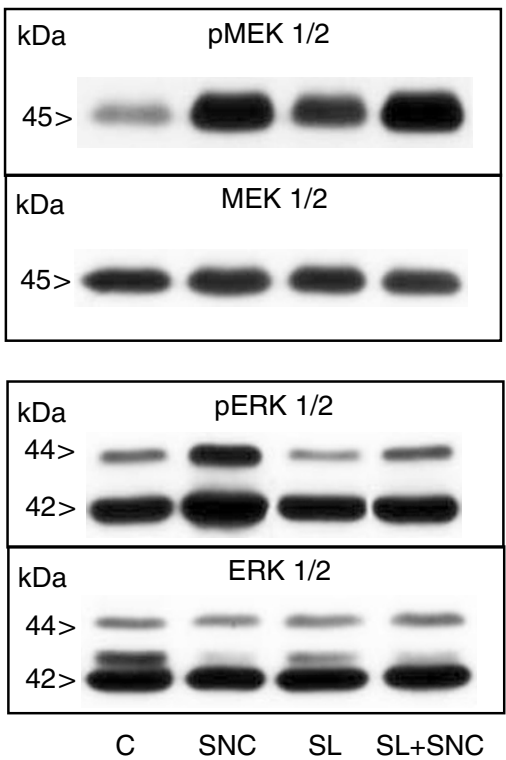

d
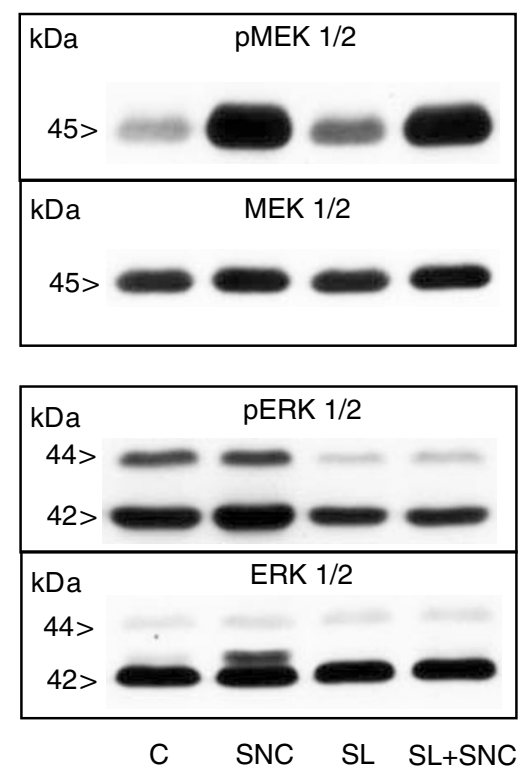

Figure 7 Effects of SL 327 (a selective MEKI/2 inhibitor) on the down-regulation of FADD immunodensity induced by the $\delta$-agonist SNC-80 in rat brain (cerebral cortex and corpus striatum). (a, b) Groups of treatments: saline (C, $n=5-6), \mathrm{SNC}-80$ (SNC, $10 \mathrm{mg} / \mathrm{kg}, \mathrm{i} . \mathrm{p} ., 30 \mathrm{~min} ; n=4), \mathrm{SL} 327$ (SL, $20 \mathrm{mg} / \mathrm{kg}$, i.p., $90 \mathrm{~min} ; n=3)$ and SL + SNC $(n=4)$. Columns are means \pm SEM of $n$ experiments per group with an animal per experiment, and expressed as percentage of saline-treated rats. One-way ANOVA detected significant differences between the groups of treatments in the cortex $(F(3,12)=5.67$, $p=0.01)$ and striatum $(F(3,12)=4.87, p=0.02)$ : ${ }^{*} p<0.05$ when compared with the corresponding saline group; ${ }^{\dagger} p<0.05$ when compared with the corresponding SNC-80 group (ANOVA followed by Bonferroni's test). Bottom (a, b): representative immunoblots of FADD and $\beta$-actin (loading control) for each set of experiments (sample: $40 \mu \mathrm{g}$ protein). (c, d) Representative immunoblots of phosphorylated MEKI/2 (pMEK) and ERKI/2 (pERK or p44/42 MAP kinases) and total MEK and ERK proteins in the cortex and striatum after treatments of rats with saline (C), SNC-80 (SNC), SL 327 (SL), and SL 327 + SNC-80 as above. See text for mean results.

proteins that constitute the DISC (Fas, FADD, and caspase8) are constitutively present in brain tissue. The DISC appears to contain a specific stoichiometric ratio of proteins $(3: 3: 3)$, which are organized by the trimeric structure of the preassembled Fas receptor (Siegel et al, 2000). In fact, mutant (defective) Fas cannot recruit three FADD molecules and consequently do not form a DISC (review in Tibbetts et al, 2003). In rat brain tissue, only the monomeric form of procaspase- 8 was immunodetected as described in other cell systems (see Donepudi et al, 2003). In contrast, the monomeric form of FADD (about $25 \mathrm{kDa}$ ) was not detected in the postnatal (P1-P22) rat cerebral cortex (Cheema et al, 1999), or it showed a very weak signal in the adult rat cortex (current results). In the human brain, the FADD monomer was readily immunodetected with a species-specific monoclonal antibody (cf. Figure 1c). Therefore, FADD protein (antibody $\mathrm{H}-181$ ) in the rat brain is mainly expressed as homo-dimer/trimer forms as reported in this study. In line 
Table I Effects of Various Opiate Drug Treatments on Caspase-8 and Caspase-3 Protein Immunoreactivities in the Rat Cerebral Cortex

\begin{tabular}{|c|c|c|c|c|c|}
\hline \multirow{2}{*}{ Treatment (time) } & \multirow{2}{*}{ Dose (mg/kg) } & \multicolumn{2}{|c|}{ Caspase-8 (55 kDa) } & \multicolumn{2}{|c|}{ Caspase-3 (32 kDa) } \\
\hline & & (\% value) & $n$ & (\% value) & $n$ \\
\hline Sufentanil (60 min) & 0.015 & $72 \pm 9$ & 4 & $95 \pm 6$ & 4 \\
\hline Chronic saline (5 days) & - & $100 \pm 2$ & 8 & $100 \pm 2$ & 5 \\
\hline Chronic morphine (5 days) & $10-100$ & $106 \pm 8$ & 6 & $96 \pm 3$ & 5 \\
\hline + Naloxone & 2 & $111 \pm 9$ & 7 & $88 \pm 4$ & 5 \\
\hline$+\mathrm{SW} 48 \mathrm{~h}$ & - & $97 \pm 3$ & 4 & $93 \pm 11$ & 5 \\
\hline Chronic SNC-80 (5 days) & 10 & $114 \pm 8$ & 4 & $95 \pm 2$ & 5 \\
\hline+ Naltrindol & 5 & $117 \pm 7$ & 5 & $103 \pm 5$ & 5 \\
\hline Saline & - & $102 \pm 7$ & 6 & $100 \pm 4$ & 10 \\
\hline U 50488-H (I h) & 10 & $94 \pm 7$ & 4 & $99 \pm 7$ & 8 \\
\hline Chronic saline (5 days) & - & $100 \pm 9$ & 5 & $100 \pm 6$ & 5 \\
\hline Chronic U 50488-H (5 days) & 10 & $100 \pm 12$ & 5 & $109 \pm 9$ & 5 \\
\hline + Nor-binaltorphimine & 5 & $98 \pm 14$ & 5 & $107 \pm 12$ & 5 \\
\hline
\end{tabular}

Data represent mean \pm SEM, and are expressed as percentage of the corresponding saline group (I00\%). SW: spontaneous withdrawal. Student's t-test or ANOVA followed by Bonferroni's test did not detect significant changes after the various treatments.

with this, Fas receptor $(35 \mathrm{kDa})$ aggregates of about $110 /$ $120 \mathrm{kDa}$ (trimers) have been also identified in the rat brain (García-Fuster et al, 2004a).

The main results indicate that (1) the acute treatments with $\mu^{-}$(sufentanil, morphine), $\delta$ - (SNC-80), and $\kappa$ (U50488H) opiate agonists induced marked decreases in the density of FADD through the activation of the corresponding opioid receptor; (2) the repeated administration of opiate drugs resulted in the induction of tachyphylaxis to their acute inhibitory effects on FADD; (3) opiate withdrawal in $\mu$ - and $\delta$-opiate-dependent rats was also associated with a reduction in FADD density; and (4) a selective MEK1/2 inhibitor (SL 327) prevented the decrease of FADD induced by SNC-80, demonstrating the involvement of ERK1/2 activation in the in vivo regulation of this protein in the brain.

Concerning the acute effects of opiate drugs, sufentanil and morphine induced bell-shaped dose effects on the immunodensity of FADD (increases and decreases), although the inhibitory effects were more remarkable, as it was the case for SNC-80 and U50488H. In this context, opiate drugs and various apoptotic agents have been shown to induce biphasic effects in multiple biological systems, with moderate stimulatory responses and marked inhibitory effects (Calabrese, 2001a, b). The present data demonstrate that $\mu-, \delta$-, and $\kappa$-opioid receptors may all have a role in the acute pharmacologic regulation of FADD, although recent findings indicate a preponderant input of the $\delta$-receptor in the functional regulation of this key apoptotic protein in the brain. Thus, it has been observed that in $\delta$-opioid receptordeficient mice, but not in $\mu$ - and $\kappa$-receptor knockout mice, the basal immunodensity of FADD is increased in the cerebral cortex $(48 \pm 12 \%, n=5, p<0.01)$, suggesting the existence of an endogenous opioid tone that, acting on $\delta$ receptors, tonically inhibits FADD expression in the brain (García-Fuster et al, 2004b; submitted for publication). Moreover, it is of interest to note that treatment of rats with the cannabinoid $\mathrm{CB}_{1}$ receptor agonist WIN 55,212-2, at doses ( 4 and $8 \mathrm{mg} / \mathrm{kg}$ ) that induce significant neurochemical effects in the CNS (Moranta et al, 2004), did not result in decreases of FADD content in the brain. This finding could suggest some specificity of opioid receptors in the modulation of FADD or, at least, that not all Gi/o protein-coupled receptors can mediate the inhibition of this protein in the brain upon receptor stimulation.

In constrast to the acute treatments with $\mu-, \delta$-, and $\kappa$ agonists on FADD (reduced content), the chronic administration (5 days) of morphine, SNC-80, and U50488H resulted in the induction of marked tachyphylaxis to the initial inhibitory effects of the opiates, which most probably reflected the corresponding process of receptor desensitization reported after repeated agonist exposure (Okura et al, 2003; Liu-Chen, 2004; Dang and Williams, 2004). Notably, in $\mu$ - and $\delta$-, but not in $\kappa$-, opiate-dependent rats, antagonistprecipitated or spontaneous opiate withdrawal induced a new and sustained inhibitory stimulus on FADD (lasting 

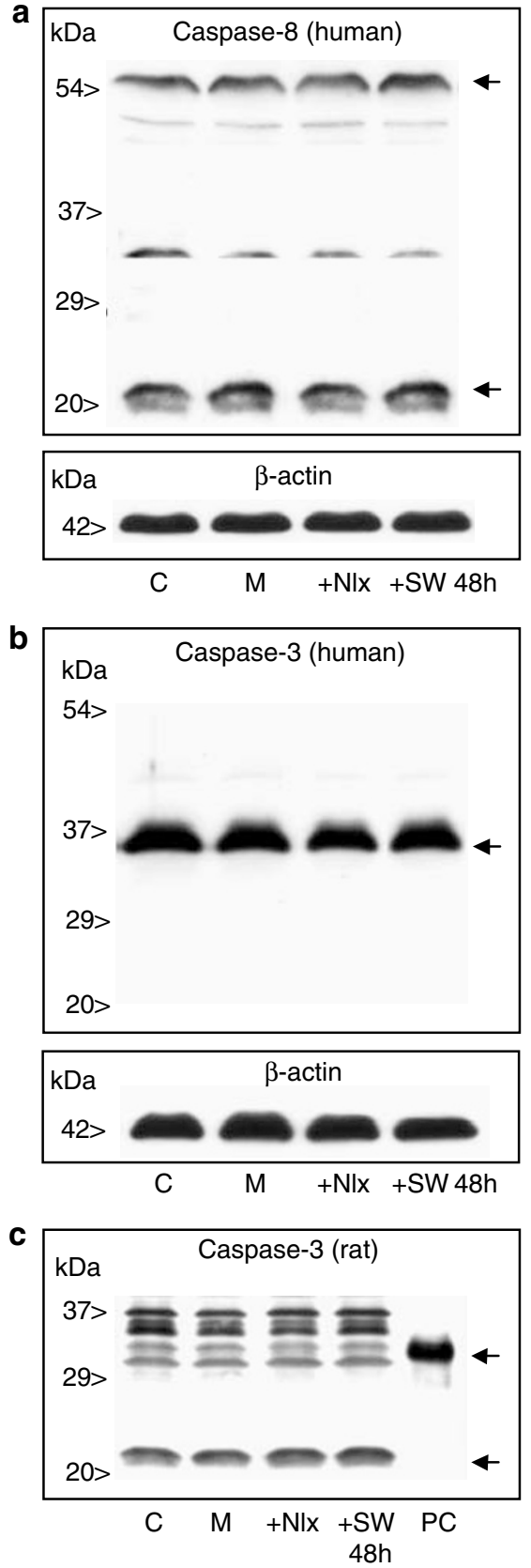

Figure 8 Representative immunoblots of (a) human $55 \mathrm{kDa}$ procaspase-8 and $\approx$ p20 kDa cleavage form (arrows), (b) human $32 \mathrm{kDa}$ procaspase-3 (arrow), and (c) rat $32 \mathrm{kDa}$ pro-caspase-3 and $\approx$ p20 kDa cleavage form (arrows; PC: positive control), as well as the corresponding for $\beta$-actin (loading control) protein immunoreactivities in the cerebral cortex of control and morphine-dependent rats (samples: $40 \mu \mathrm{g}$ protein). Effects of chronic saline (C), chronic morphine (M, 10-100 mg/kg for 5 days), and chronic morphine followed by naloxone ( $\mathrm{Nlx}, 2 \mathrm{mg} / \mathrm{kg}$, i.p.)precipitated $(2 \mathrm{~h}$ ) or spontaneous (SW, $48 \mathrm{~h}$ ) opiate withdrawal (see also Table I).

more than 2 days in the case of morphine withdrawal), which could be related to the large increase in the release of enkephalins (endogenous ligands for $\mu$ - and $\delta$-opioid receptors) observed in the brains of chronic morphinewithdrawn rats (Mas Nieto et al, 2002), which also displayed higher numbers of c-Fos-positive neurons identified as enkephalinergic neurons (Veinante et al, 2003).
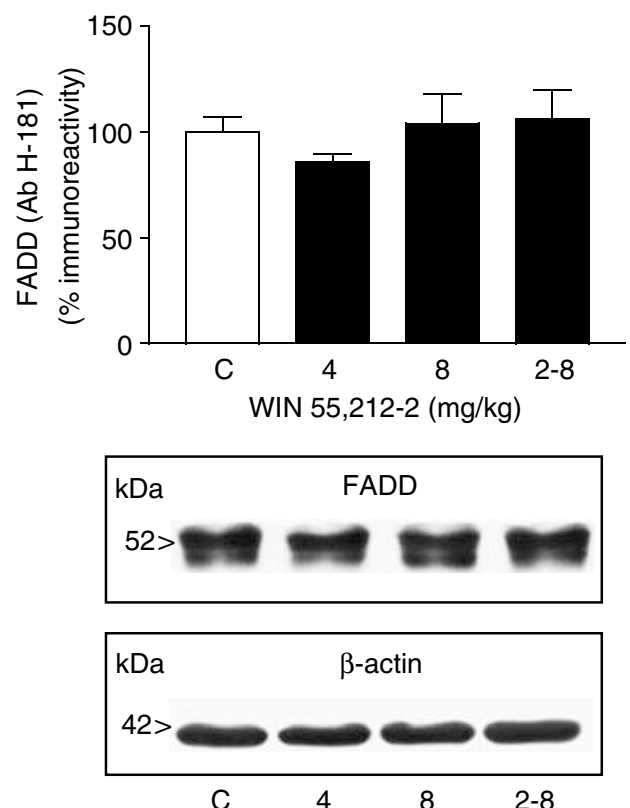

Figure 9 Acute and chronic effects of the cannabinoid $C B_{1}$ receptor agonist WIN 55,2I2-2 on FADD immunodensity in rat brain (cerebral cortex). Groups of treatments: saline $(\mathrm{C}, n=8)$, acute WIN (4 and $8 \mathrm{mg} / \mathrm{kg}$, i.p., I $\mathrm{h} ; n=4-5)$ and chronic WIN (2-8 mg/kg, i.p. for 5 days; $n=6)$. Columns are means \pm SEM of $n$ experiments per group with an animal per experiment, and expressed as percentage of saline-treated rats. One-way ANOVA did not detect a significant difference between the groups of treatments $(F(3,19)=0.74, p=0.54)$. Bottom: representative immunoblot of FADD for the various treatments, and the corresponding for $\beta$-actin as a loading control (sample: $40 \mu \mathrm{g}$ protein).

A relevant finding of this investigation was the identification of a molecular mechanism (activation of ERK1/2 MAPK signaling) responsible for the ability of the $\delta$-agonist SNC-80 to decrease FADD content in the brain. Thus, treatment of rats with $20 \mathrm{mg} / \mathrm{kg}$ of SL 327 (a dose that selectively blocks MEK1/2 activity and induces significant neurochemical effects in the CNS; see Ferguson and Robinson, 2004), abolished the decrease in FADD produced by SNC- 80 in the cerebral cortex and corpus striatum. Moreover, and as expected, SL 327 was also able to block the activation of ERK1/2, but not that of MEK1/2, induced by SNC-80. These results clearly demonstrated the direct involvement of the two MAPKs (sequential activation of MEK and ERK) in the in vivo regulation of FADD by the opiate agonist. The same molecular mechanism can be postulated for the inhibitory effect of morphine on FADD, since this opiate also activated ERK1/2 in the rat brain and it failed to do so in SH-SY5Y cells after inhibition (PD98059) of MEK1/2 (Ferrer-Alcón et al, 2004). It should be mentioned that inhibition of MAPK signaling (SL 327) did not modify the various forms of Fas quantitated in the same brain samples, excluding alterations in the density of this receptor in the regulation of FADD.

The reduction of FADD content induced by opiate drugs may be related to the recently uncovered neuroprotective or survival-promoting effects associated with extra-analgesic doses of opiates (acute effects) in various systems (Tegeder and Geisslinger, 2004). In the CNS, Fas activation was shown to induce apoptosis (Felderhoff-Mueser et al, 2000; Sastry 
and Rao, 2000) or, conversely, to deliver survival signals (eg neurite growth, Desbarats et al, 2003). In previous studies in rats (Boronat et al, 2001; García-Fuster et al, 2003a, 2004a), heroin/morphine addiction and opiate withdrawal were associated with upregulation of Fas in the brain (ie, increased content of native receptor and complexes of monomers relevant in Fas signaling). In the current study, FADD, the adaptor protein that couples Fas to caspase- 8 and transmits the death signal, followed an opposite modulation. Together, the results suggest that possible apoptotic signals engaged by Fas activation (see Tegeder and Geisslinger, 2004; Liao et al, 2005) would be offset by decreased signal transduction through FADD and effector caspases-8/3 (not altered by any opiate treatment). Since the activation of ERK1/2 is crucial for various antiapoptotic mechanisms (Wada and Penninger, 2004), including protection against Fas-mediated apoptosis (Holmström et al, 1999, 2000), it is tempting to conclude that opiate drugs (and specifically the $\delta$-agonists) could promote survival signals in the brain through inhibition of FADD, which in turn is dependent on the activation of ERK1/2 signaling. In this context, recent studies have shown that activation of $\delta$-opioid receptors can protect neocortical neurons from glutamate excitotoxicity (Zhang et al, 2000) and induce other cytoprotective effects (Barry and Zuo, 2005).

\section{ACKNOWLEDGEMENTS}

This study was supported by grants SAF2004-03685 from the Ministerio de Educación y Ciencia (Programa Nacional de Biomedicina, MEC and FEDER, Madrid, Spain) and PRIB-2004-10147 (Conselleria d'Economia, Hisenda i Innovació, Govern Balear, Palma de Mallorca, Spain). MJG$\mathrm{F}$ was supported by a predoctoral fellowship from CSIC/ MEC-Associated Units (Madrid, Spain). JAG-S is a member of the Institut d'Estudis Catalans (Barcelona, Spain).

\section{REFERENCES}

Abdolzade-Bavil A, Hayes S, Goretzki L, Kröger M, Anders J, Hendriks R (2004). Convenient and versatile subcellular extraction procedure, that facilitates classical protein expression profiling and functional protein analysis. Proteomics 4: 1397-1405.

Algeciras-Schimnich A, Shen L, Barnhart BC, Murmann AE, Burkhardt JK, Peter ME (2002). Molecular ordering of the initial signaling events of CD95. Mol Cell Biol 22: 207-220.

Ammon S, Mayer P, Riechert U, Tischmeyer H, Höllt V (2003). Microarray analysis of genes expressed in the frontal cortex of rats chronically treated with morphine and after naloxone precipitated withdrawal. Mol Brain Res 112: 113-125.

Barnhart BC, Alappat EC, Peter ME (2003). The CD95 typeI/type II model. Sem Immunol 15: 185-193.

Barry U, Zuo Z (2005). Opioids: Old drugs for potential new applications. Curr Pharm Des 11: 1343-1350.

Boronat MA, García-Fuster MJ, García-Sevilla JA (2001). Chronic morphine induces up-regulation of the pro-apoptotic Fas receptor and down-regulation of the anti-apoptotic Bcl-2 oncoprotein in rat brain. Br J Pharmacol 134: 1263-1270.

Brandt MR, Furness MS, Rice KC, Fischer BD, Negus S (2001). Studies of tolerance and dependence with the $\delta$-opioid agonist SNC80 in rhesus monkeys responding under a schedule of food presentation. J Pharmacol Exp Ther 299: 629-637.
Budd RC (2002). Death receptors couple to both cell proliferation and apoptosis. J Clin Invest 109: 437-442.

Büttner A, Mall G, Penning R, Weis S (2000). The neuropathology of heroin abuse. Foren Sci Intern 113: 435-442.

Calabrese EJ (2001a). Opiates: biphasic dose responses. Crit Rev Toxicol 31: 585-604.

Calabrese EJ (2001b). Apoptosis: biphasic dose responses. Crit Rev Toxicol 31: 607-613.

Cheema ZF, Wade SB, Sata M, Walsh K, Sohrabji F, Miranda RC (1999). Fas/Apo [apoptosis]-1 and associated proteins in the differentiating cerebral cortex: induction of caspase-dependent cell death and activation of NF- $\kappa$ B. J Neurosci 19: 1754-1770.

Chinnaiyan AM, O’Rourke K, Tewari M, Dixit VM (1995). FADD, a novel death domain-containing protein, interacts with the death domain of Fas and initiates apoptosis. Cell 81: 505-512.

Cohen GM (1997). Caspases: the executioners of apoptosis. Biochem J 326: 1-16.

Dang VC, Williams JT (2004). Chronic morphine treatment reduces recovery from opioid desensitization. J Neurosci 24: 7699-7706.

Desbarats J, Birge RB, Minouni-Rongy M, Weistein DE, Palerme JS, Newell MK (2003). Fas engagement induces neurite growth through ERK activation and p35 upregulation. Nat Cell Biol 5: 118-125.

Donepudi M, Mac Sweeney A, Briand C, Grütter MG (2003). Insights into the regulatory mechanism for caspase- 8 activation. Mol Cell 11: 543-549.

Downer EJ, Fogarty MP, Campbell VA (2003). Tetrahydrocannabinol-induced neurotoxicity depends on $\mathrm{CB}_{1}$ receptor-mediated c-Jun N-terminal kinase activation in cultured cortical neurons. Br J Pharmacol 140: 547-557.

Felderhoff-Mueser U, Taylor DL, Greenwood K, Kozma M, Stibenz D, Joashi UC et al (2000). Fas/CD95/APO-1 can function as a death receptor for neuronal cells in vitro and in vivo and is upregulated following cerebral hypoxic-ischemic injury to the developing rat brain. Brain Pathol 10: 17-29.

Ferguson SM, Robinson TE (2004). Amphetamine-evoked gene expression in striatopallidal neurons: regulation by corticostriatal afferents and the ERK/MAPK signaling cascade. J Neurochem 91: 337-348.

Ferrer-Alcón M, García-Fuster MJ, La Harpe R, García-Sevilla JA (2004). Long-term regulation of signalling components of adenylyl cyclase and mitogen-activated protein kinase in the pre-frontal cortex of human opiate addicts. J Neurochem 90: 220-230.

Ferrer-Alcón M, García-Sevilla JA, Jaquet PE, La Harpe R, Riederer $\mathrm{BM}$, Walzer C et al (2000). Regulation of nonphosphorylated and phosphorylated forms of neurofilament proteins in the prefrontal cortex of human opioid addicts. J Neurosci Res 61: 338-349.

Gabilondo AM, García-Sevilla JA (1995). Spontaneous withdrawal from long-term treatment with morphine accelerates the turnover of $\alpha_{2}$-adrenoceptors in rat brain: up-regulation of receptors associated with increased receptor appearance. J Neurochem 64: 2590-2597.

García-Fuster MJ, Ferrer-Alcón M, Miralles A, García-Sevilla JA (2003a). Modulation of Fas receptor proteins and dynamin during opiate addiction and induction of opiate withdrawal in rat brain. Naunyn-Schmiedeberg's Arch Pharmacol 368: 421-431.

García-Fuster MJ, Ferrer-Alcón M, Miralles A, García-Sevilla JA (2004a). Deglycosylation of Fas receptor and chronic morphine treatment up-regulate high molecular mass Fas aggregates in the rat brain. Eur J Pharmacol 496: 63-69.

García-Fuster MJ, Miralles A, García-Sevilla JA (2003b). Regulation of Fas-associated death domain (FADD) protein during opiate addiction in the rat brain. Meth Find Exp Clin Pharmacol 25(Suppl. A): 125. 
García-Fuster MJ, Miralles A, Martín M, Maldonado R, GarcíaSevilla JA (2004b). Fas receptor and Fas-associated death domain (FADD) in the cerebral cortex of $\mu$-, $\delta$-, or $\kappa$-opioid receptor knock-out mice. Meth Find Exp Clin Pharmacol 26(Suppl. A): 78.

Gómez-Angelats M, Cidlowski JA (2003). Molecular evidence for the nuclear localization of FADD. Cell Death Differ 10: 791-797.

Henkler F, Behrle E, Dennehy KM, Wicovsky A, Peters N, Warnke $C$ et al (2005). The extracellular domains of FasL and Fas are sufficient for the formation of supramolecular FasL-Fas clusters of high stability. J Cell Biol 168: 1087-1098.

Holmström TH, Schmitz I, Söderström TS, Poukkula M, Johnson VL, Chow SC et al (2000). MAPK/ERK signaling in activiated T cells inhibits CD95/Fas-mediated apoptosis downstream of DISC assembly. EMBO J 19: 5418-5428.

Holmström TH, Tran SEF, Johnson VL, Ahn NG, Chow SC, Eriksson JE (1999). Inhibition of mitogen-activated kinase signaling sensitizes HeLa cells to Fas receptor-mediated apoptosis. Mol Cell Biol 19: 5991-6002.

Kischkel FC, Hellbardt S, Behrmann I, Germer M, Pawlita M, Krammer PH et al (1995). Cytotoxicity-dependent APO-1 (Fas/ CD95)-associated proteins form a death-inducing signaling complex (DISC) with the receptor. EMBO J 14: 5579-5588.

Kolch W, Calder M, Gilbert D (2005). When kinases meet mathematics: the systems biology of MAPK signalling. FEBS Lett 579: 1891-1895.

Kyosseva SV (2004). Mitogen-activated protein kinase signaling. Int Rev Neurobiol 59: 201-220.

Lambert C, Landau AM, Desbarats J (2003). Fas-beyond death: a regenerative role for Fas in the nervous system. Apoptosis 8: 551-562.

Liao D, Lin H, Law PY, Loh HH (2005). Mu-opioid receptors modulate the stability of dendritic spines. Proc Natl Acad Sci USA 102: 1725-1730.

Liu-Chen L-Y (2004). Agonist-induced regulation and trafficking of $\kappa$ opioid receptors. Life Sci 75: 511-536.

MacEwan DJ (2002). TNF ligands and receptors a matter of life and death. Br J Pharmacol 135: 855-875.

Marie-Claire C, Courtin C, Roques BP, Noble F (2004). Cytoskeletal genes regulation by chronic morphine treatment in rat striatum. Neuropsychopharmacology 29: 2208-2215.

Mas Nieto M, Wilson J, Cupo A, Roques BP, Noble F (2002). Chronic morphine treatment modulates the extracellular levels of endogenous enkephalins in rat brain structures involved in opiate dependence: a microdialysis study. J Neurosci 22: 10341041.

Milanés MV, Laorden ML (1998). Effects of U-50,488H withdrawal on catecholaminergic neurones of the rat ventricle. $\mathrm{Br} J$ Pharmacol 124: 1060-1064.

Miralles A, Esteban S, Sastre-Coll A, Moranta D, Asensio VJ, García-Sevilla JA (2005). High-affinity binding of $\beta$-carbolines to imidazoline $\mathrm{I}_{2 \mathrm{~B}}$ receptors and MAO-A in rat tissues: Norharman blocks the effect of morphine withdrawal on DOPA/noradrenaline synthesis in the brain. Eur J Pharmacol 518: 234-242.

Moranta D, Esteban S, García-Sevilla JA (2004). Differential effects of acute cannabinoid drug treatment, mediated by $\mathrm{CB}_{1}$ receptors, on the in vivo activity of tyrosine and tryptophan hydroxylase in the rat brain. Naunyn-Schmiedeberg's Arch Pharmacol 369: $516-524$

Nagata S, Golstein P (1995). The Fas death receptor. Science 267: 1449-1456.

Nestler EJ (1996). Under siege: the brain on opiates. Neuron 16: 897-900.

Okura T, Varga EV, Hosohata Y, Navratilova E, Cowell SM, Rice K et al (2003). Agonist-specific down-regulation of the human $\delta$-opioid receptor. Eur J Pharmacol 459: 9-16.

Powles T, Poele R, Shamash J, Chaplin T, Propper D, Joel S et al (2005). Cannabis-induced cytotoxicity in leukemic cell lines: the role of the cannabinoid receptors and the MAPK pathway. Blood 105: 1214-1221.

Sastry PS, Rao KS (2000). Apoptosis and the nervous system. J Neurochem 74: 1-20.

Scaffidi C, Volkland J, Blomberg I, Hoffmann I, Krammer PH, Peter ME (2000). Phosphorylation of FADD/MORT1 at serine 194 and association with a $70-\mathrm{kDa}$ cell cycle-regulated protein kinase. J Immunol 164: 1236-1242.

Scherle PA, Ma W, Lim H, Dey S, Traskos JM (2000). Regulation of cyclooxygenase-2 induction in the mouse uterus during decidualization. J Biol Chem 275: 37086-37092.

Siegel RM, Ka-Ming Chang F, Chun HJ, Lenardo MJ (2000). The multifaceted role of Fas signaling in immune cell homeostasis and autoimmunity. Nat Immunol 1: 469-474.

Tegeder I, Geisslinger G (2004). Opioids as modulators of cell death and survival unraveling mechanisms and revealing new indications. Pharmacol Rev 56: 351-369.

Tibbetts MD, Zheng L, Lenardo MJ (2003). The death effector domain protein family: regulators of cellular homeostasis. Nat Immonol 4: 404-409.

Tourneur L, Buzyn A, Chiocchia G (2005). FADD adaptor in cancer. Med Immunol 4: 1-9.

Veinante P, Stoeckel M-E, Lasbennes F, Freund-Mercier M-J (2003). c-Fos and peptide immunoreactivities in the central extended amygdala of morphine-dependent rats after naloxoneprecipitated withdrawal. Eur J Neurosci 18: 1295-1305.

Vogel S, Kubin T, Von der Ahe D, Deindl E, Schaper W, Zimmermann R (2005). MEK hyperphosphorylation coincides with cell cycle shut down of cultured smooth muscle cells. J Cell Physiol (in press) (published online: 26 May 2005).

Wada T, Penninger JM (2004). Mitogen-activated protein kinases in apoptosis regulation. Oncogene 23: 2838-2849.

Wang J, Charboneau R, Barke RA, Loh HH, Roy S (2002). Opioid receptor mediates chronic restraint stress-induced lymphocyte apoptosis. J Immunol 169: 3630-3636.

Yin D, Mufson RA, Wang R, Shi Y (1999). Fas-mediated cell death promoted by opioids. Nature 397: 218 .

Zhang J, Haddad GG, Xia Y (2000). Delta-, but not mu- and kappa-, opioid receptor activation protects neocortical neurons from glutamate-induced excitotoxic injury. Brain Res 885: 143-153.

Zhang J, Winoto A (1996). A mouse Fas-associated protein with homology to the human Mort1/FADD protein is essential for Fas-induced apoptosis. Mol Cell Biol 16: 2756-2763.

Zhang J, Zhang D, Hua Z (2004). FADD and its phosphorylation. IUBMB Life 56: 395-401. 